\title{
Empirical Analysis on Efficiency of Listed Real Estate Companies in China by DEA
}

\author{
Qiting Chen, Fengdan Li \\ Nanjing University of Aeronautics and Astronautics, Nanjing, China \\ Email:chen_qiting@163.com,1fdnuaa@163.com
}

How to cite this paper: Chen, Q.T. and Li, F.D. (2017) Empirical Analysis on Efficiency of Listed Real Estate Companies in China by DEA. iBusiness, 9, 49-59.

https://doi.org/10.4236/ib.2017.93004

Received: August 1, 2017

Accepted: August 27, 2017

Published: August 30, 2017

Copyright (๑) 2017 by authors and Scientific Research Publishing Inc. This work is licensed under the Creative Commons Attribution International License (CC BY 4.0).

http://creativecommons.org/licenses/by/4.0/

\begin{abstract}
The real estate industry plays an important role in the economic development in China. The purposes of this paper are to measure the operating efficiency of the real estate industry and also compare the different influencing factors on the efficiency. 30 companies listed in Shenzhen and Shanghai markets are selected as the sample companies of operating efficiency study. The data is collected from 2009 until 2015. $C^{2} R$ and $B^{2} C$ models of the data envelopment analysis (DEA) are used to derive findings. The present study applied Tobit regression model to study different factors' influence on the efficiency. We concluded that efficiency was not high among most companies and the efficiency gap was quite wide. The results of the Tobit regression model showed that the efficiency was positively correlated with the net interest rate and education level, not so correlated with proportion of the first major shareholders and negatively with asset-liability ratio. Based on the conclusions, the paper put forward some specific suggestions.
\end{abstract}

\section{Keywords}

DEA, Efficiency Evaluation, Real Estate Industry, Tobit Regression Model

\section{Introduction}

As we can see from Figure 1, the main business income of the estate industry has increased from year to year. Refer to the data released by the National $\mathrm{Bu}$ reau of statistics in 2016, the real estate industry's output value contributed 6.5\% GDP for the year. Real estate industry directly drives the development of multiple industries. Therefore, the healthy development of real estate has a direct impact on the development of China's national economy; real estate industry has been the financial core during the last ten years. The healthy operation is the cornerstone of China's financial security. 


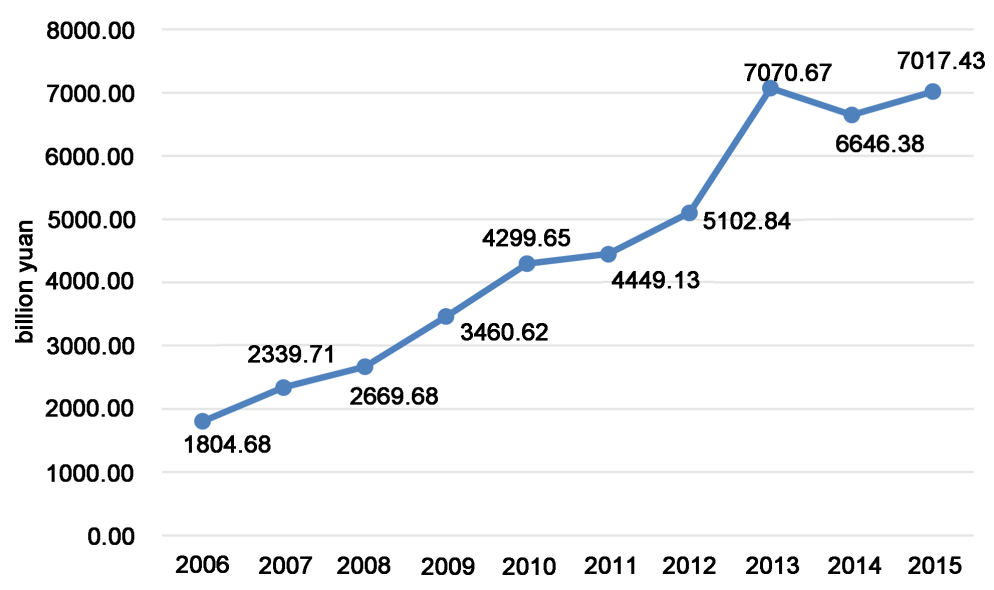

Figure 1. Revenue from principle business of enterprises for real estate development. Sources: national bureau of statistics.

In the company-level perspective, it's necessary to improve operating efficiency because efficiency is a central problem (perhaps the only central problem) to be studied in economics.

\section{DEA Model and Efficiency Measurement}

\subsection{Literature Review}

In the new era, how to improve the overall efficiency of the industry is the focus of the real estate industry and academia. According to the current researches, there are two main aspects of DEA method to analyze the efficiency of listed real estate companies.

The first aspect is to use DEA method to evaluate the overall efficiency of enterprises. For instance, Liu Yongle et al. found that tightening of macroeconomic policy possibly lead enterprises to diminishing returns to scale [1]. Zhang Bo selected two-stage DEA model to analysis 26 enterprises. The results showed that there was no significant correlation between operating efficiency and effectiveness [2]. Meng Chuanjin et al. compared 15 real estate enterprises' technical efficiency, pure technical efficiency and scale efficiency in 2006, and finally concluded that concentrating on single administration many efficient lead enterprises to develop [3]. Yuan Fang et al. explored the data of 20 companies in 2000-2007, they found the operational efficiency of China's real estate industry was high, but the local volatility was large. In the end, they put forward some corresponding measures [4]. Fu Chunxiang et al. research results prove that the overall efficiency of the enterprises is relatively stable, but the impact of the financial crisis is relatively large [5]. He Zhiyong proved and his results showed that China's current real estate management efficiency is not ideal, and land purchase redundancy phenomenon is serious [6].

It can be seen from the analysis above about the papers on DEA that at the same time when the authors used DEA method, they were also proving that the results of the method were reasonable. Meng Chuanjin et al. also mentioned that 
DEA was an effective method for the authors because the results were obvious [3]. In addition, enterprises with lower efficiencies can be aware of their own shortages and learn from the better performance of the enterprises to make out the plans for adjustment. DEA method provides a way for the researchers to find out potential problems of the enterprises, especially in industries where the competition is so intense, just like the real industry. Therefore, DEA method can help enterprises to develop in the right direction.

On the other hand, we speculate the influence factors based on efficiency value. Wang Ting et al. finally found that the national macroeconomic policy played a great part in the industry efficiency, and the composite stock index has little effect on it [7]. Ju Song and Shen Chenjiang set up a model to evaluate performance of the listed enterprises [8] [9]. Shen used DEA and Malmquist index method to describe that the correlation between ownership concentration and operating efficiency is not significant, it may because few people will do harm to the interests of enterprises in the highly concentrated company. Zhou Zhuohua et al. found that the efficiency of the company using backdoor transformation had improved significantly [10]. Lu Juchun et al. assumed a negative correlation among market concentration external expenditure and efficiency [11]. Zhang Hong et al. used statistical tests to argue in favor that the impact of corporate governance on enterprise performance is significant by comparing the mean of performance before and after the transition [12].

As is shown on the above literature analysis, DEA method has been extensively applied to measurement of the efficiency, but the research started late in China, and it still doesn't reach a high level though it has been developing in rapidly. So it needs to be utilization in more fields to reach a higher level. $\mathrm{B}^{2} \mathrm{C}$ model of DEA method is applied in the paper to measure operating efficiency of real estate listed companies and is also used to study the influence of different factors on the efficiency. Most of the scholars tend to choose financial indicators instead of non-financial indicators, leading to some problems like that the results of the analysis can't reflect the influence of the factors not considered, which means the results lack comprehensiveness. Actually, it is difficult to fully reflect the other factors affecting the efficiency of real estate industry. Tobit model is still the main method when studying. Based on this, this paper will be improved.

\subsection{DEA Evaluation Model}

DEA was developed by A. Charnes et al. in 1978 [13]. It is a well-established nonparametric methodology for evaluating the relative efficiency of a set of comparable entities called decision making units (DMUs) with multiple inputs and outputs [14]. The advantages are that it requires prior knowledge of neither the distributional form of the inefficiency term nor of the production technology used in the industry [15]. Therefore, DEA method is applied to field extensively [16] [17].

Assume that there are $\mathrm{n}$ departments or units (also called decision making 
units, namely $D M U$ ) to be evaluated. Each $D M U$ has $m$ types of input resources and $s$ types of output resources, then their input and output vectors are: $X_{j}=\left(x_{1 j}, x_{2 j}, \cdots, x_{m j}\right)^{\mathrm{T}}, j=1,2, \cdots, n, \quad Y_{j}=\left(y_{1 j}, y_{2 j}, \cdots, y_{s j}\right)^{\mathrm{T}}, j=1,2, \cdots, n$, where, $x_{i j}>0(i=1,2, \cdots, m), \quad y_{r j}>0(r=1,2, \cdots, s)$; Efficiency evaluation index for decision making units $\left(D M U_{j}, 1 \leq j \leq n\right)$ is:

$$
h_{j}=\frac{u^{\mathrm{T}} Y_{j}}{v^{\mathrm{T}} X_{j}}, j=1, \cdots, n
$$

When evaluating the comprehensive technical efficiency of the $j$ real estate enterprise, the target is efficiency index of this enterprise, and the other enterprises' efficiency indexes are constraint conditions. The $C^{2} R$ model can be expressed as followed:

$$
\begin{aligned}
& \min \theta \\
& \text { s.t. }\left\{\begin{array}{l}
\sum_{j=1}^{n} X_{j} \lambda_{j}+S^{-}=\theta X_{0} \\
\sum_{j=1}^{n} Y_{j} \lambda_{j}-S^{+}=Y_{0} \\
\lambda_{j} \geq 0, j=1, \cdots, n \\
S^{-} \geq 0, S^{+} \geq 0
\end{array}\right.
\end{aligned}
$$

$\mathrm{C}^{2} \mathrm{R}$ efficiency is also called the comprehensive technical efficiency (TE). The $\theta$ is the technical efficiency score of company $j . \theta$ ranges from 0 to 1 . If its value is equal to 1 , the $D M U$ is considered to be efficient. Conversely, it's not.

Adding a constraint to the above (2) expression, $\sum_{j=1}^{n} \lambda_{j}=1$, and then we can get $\mathrm{BC}^{2}$ model [18]. Also pure technical efficiency (PTE) can be calculated. According to the formula, $S E=T E / P T E$. When $S E=1$, the $D M U$ scale is efficient; When $S E<1$, it indicates that the $D M U$ is in a state of scale inefficiency.

\subsection{Sample Description and Index Selection}

Firstly, we need to determine the $D M U s$. In order to make the final results reflect the situation of listed real estate enterprises better, the following points are considered:

1) In this paper, we finally selected the companies which main business is real estate development and construction, and do not consider the companies involved in multi field;

2) Generally speaking, the number of $D M U s$ is more than two times the sum of the inputs and outputs.

Therefore, this article has selected 30 listed real estate enterprises. Here's the name list (Table 1).

The efficiency evaluation index system of enterprise contains input index and output index. Referring to the research of other scholars [19] [20] [21], here this paper chooses the following input indicators and output indicators as needed (Table 2): 
Table 1. The name of companies.

\begin{tabular}{|c|c|}
\hline Name & Quantity \\
\hline 1) China Vanke Co., Ltd. & $\begin{array}{l}\text { 16) Beijing Urban Construction Investment \& } \\
\text { Development Co., Ltd. }\end{array}$ \\
\hline 2) Shenzhen Zhenye (Group) Co., Ltd. & $\begin{array}{l}\text { 17) Tianjin Realty Development (Group) Co., } \\
\text { Ltd. }\end{array}$ \\
\hline 3) Shahe Industry Co., Ltd. & 18) Huafa Industrial Co., Ltd. Zhuhai \\
\hline 4) COFCO Property (Group) Co., Ltd. & 19) Beijing Capital Development Co., ltd. \\
\hline $\begin{array}{l}\text { 5) Shenzhen Centralcon Investment Holding } \\
\text { Co., Ltd. }\end{array}$ & 20) Gemdale Corporation \\
\hline $\begin{array}{l}\text { 6) AVIC Real Estate Holding Company } \\
\text { Limited }\end{array}$ & 21) Guangzhou Yuetai Group Co., Ltd. \\
\hline 7) Financial Street Holdings Co., Ltd. & 22) Nanjing Chixia Development Co., Ltd. \\
\hline $\begin{array}{l}\text { 8) Yunnan Metropolitan Real Estate } \\
\text { Development Co., Ltd. }\end{array}$ & 23) Cinda Real Estate Co., Ltd. \\
\hline $\begin{array}{l}\text { 9) Zhongtian Urban Development Group } \\
\text { Company Limited }\end{array}$ & 24) Tande Co., Ltd. \\
\hline 10) Yango Group Co., Ltd. & 25) Hua Yuan Property Co., Ltd. \\
\hline 11) China Real Estate Corporation Limited & $\begin{array}{l}\text { 26) Shanghai Industrial Development Co., } \\
\text { Ltd. }\end{array}$ \\
\hline $\begin{array}{l}\text { 12) Jiangsu Zhongnan Construction Group Co., } \\
\text { Ltd. }\end{array}$ & 27) BEIH-Property Co., Ltd. \\
\hline 13) Rise Sun Real Estate Development Co., Ltd. & 28) Shanghai Shimao Co., Ltd. \\
\hline 14) Poly Real Estate Group Co., Ltd. & $\begin{array}{l}\text { 29) Shanghai Jinqiao Export Processing Zone } \\
\text { Development Co., Ltd. }\end{array}$ \\
\hline 15) Wolong Real Estate Group Co., Ltd. & $\begin{array}{l}\text { 30) Shanghai Lujiazui Finance \& Trade Zone } \\
\text { Development Co., Ltd. }\end{array}$ \\
\hline
\end{tabular}

Table 2. The input indicators and output indicators.

\begin{tabular}{|c|c|c|c|}
\hline $\begin{array}{c}\text { Input } \\
\text { indicators }\end{array}$ & Meaning & $\begin{array}{c}\text { Output } \\
\text { indicators }\end{array}$ & Meaning \\
\hline $\begin{array}{c}\text { Main } \\
\text { business cost }\end{array}$ & $\begin{array}{l}\text { The main business cost } \\
\text { refers to the cost of the } \\
\text { company in the production } \\
\text { and sales, which determines } \\
\text { the profitability of the } \\
\text { enterprise directly. }\end{array}$ & $\begin{array}{l}\text { Main } \\
\text { business } \\
\text { income }\end{array}$ & $\begin{array}{l}\text { Main business income refers to } \\
\text { the income obtained by } \\
\text { enterprises during their business } \\
\text { activities, which reflects the } \\
\text { profitability of the company's } \\
\text { main business. }\end{array}$ \\
\hline Total assets & $\begin{array}{l}\text { Total assets are all assets } \\
\text { owned by the enterprise, } \\
\text { which can produce } \\
\text { economic benefits if made } \\
\text { full use of them. }\end{array}$ & $\begin{array}{l}\text { Gross } \\
\text { profit }\end{array}$ & $\begin{array}{l}\text { Gross profit is the income earned } \\
\text { by the enterprise after deducting } \\
\text { the cost, which shows not only } \\
\text { the profit and loss of enterprises, } \\
\text { but also reflects the management } \\
\text { efficiency. }\end{array}$ \\
\hline $\begin{array}{l}\text { The number } \\
\text { of employees }\end{array}$ & $\begin{array}{l}\text { Employees are the source of } \\
\text { all the value of the } \\
\text { enterprise }\end{array}$ & $\begin{array}{c}\text { Return on } \\
\text { equity }\end{array}$ & $\begin{array}{l}\text { Return on equity is the ratio of } \\
\text { after-tax profits and net assets, } \\
\text { which can measure the efficiency } \\
\text { of the enterprise using its own } \\
\text { capital. }\end{array}$ \\
\hline
\end{tabular}




\subsection{Empirical Results and Analysis}

This paper deals with the data of 30 listed real estate enterprises during 20092015. With the help of DEAP, we finally get the calculation results of the model: the average value of the technical efficiency, pure technical efficiency and scale efficiency of the 30 enterprises operating efficiency every year, donated by TE, PTE and SE respectively. The calculation results are shown in Table 3.

Table 3 shows that the average value of the technical efficiency is not very high, and it still has a development space. Among 30 listed companies, there are only 10 to 17 companies which are DEA effective. The number of enterprises which are DEA effective most is in 2013, but it only accounts for $56.67 \%$ of the total. Besides, the fluctuation of technical efficiency is also large: it shows an upward trend in 2009-2013, because the country has adopted a series of measures to expand domestic demand after the financial crisis. It begins to decline after 2013. And it drops a lot. Due to the overheated real estate, the State Council issued a series of policies to control the housing market, such as Eight Control Regulations on House Prices.

From the view of the general trend of pure technical efficiency, pure technical efficiency increases in 2009-2011, and begins to decline in 2012. It reaches lowest value in 2013 and continued to rise from 2014. Taking one with another, the value of pure technical efficiency is higher than technical efficiency. It illustrates the enterprise management level and technical level promote, striving to consolidate their core competitiveness.

From objective data analysis, most listed real estate enterprises are in the situation of the scale inefficiency. But in comparison, the scale efficiency is higher than the pure technical efficiency. This shows that after the financial crisis, in order to stimulate consumer investment, the country increases support efforts to the real estate industry, making listed real estate companies gain a certain scale economic effect.

From the above Table 4, during the period of 2009-2015, less than half of the enterprises are in the constant returns. It shows that they need to reform the allocation of enterprise-internal sources. The companies that not in optimal production scale may consider appropriate expansion in terms of investment,

Table 3. The average value of operating efficiency.

\begin{tabular}{cccccccc}
\hline \multirow{2}{*}{ Indicators } & \multicolumn{7}{c}{ Year } \\
\cline { 2 - 8 } & 2009 & 2010 & 2011 & 2012 & 2013 & 2014 & 2015 \\
\hline TE & 0.705 & 0.774 & 0.774 & 0.724 & 0.703 & 0.715 & 0.695 \\
PTE & 0.762 & 0.819 & 0.831 & 0.798 & 0.780 & 0.821 & 0.825 \\
SE & 0.902 & 0.931 & 0.912 & 0.887 & 0.846 & 0.865 & 0.835 \\
$\begin{array}{c}\text { The number of } \\
\text { DEA effective }\end{array}$ & 12 & 14 & 13 & 13 & 17 & 12 & 10 \\
\hline
\end{tabular}

Sources: Resset database. 
Table 4. Returns of scale.

\begin{tabular}{llll}
\hline Years & - & Irs & Drs \\
\hline 2009 & 12 & 14 & 4 \\
2010 & 14 & 13 & 3 \\
2011 & 13 & 11 & 6 \\
2012 & 13 & 12 & 5 \\
2013 & 17 & 8 & 5 \\
2014 & 12 & 7 & 11 \\
2015 & 10 & 9 & 11 \\
\hline
\end{tabular}

Sources: Resset database.

in order to obtain economies of scale, reduce the average cost. And sometimes it cannot expand the investment of production factors and should make full use of resources.

\section{Analysis of the Influencing Factors of Efficiency}

This chapter will study the influence factors of efficiency further, providing a theoretical support for the low-efficiency enterprises.

\subsection{Variable Definition}

1) Equity concentration

Equity concentration refers to the concentration ratio of the major shareholders. It reflects the distribution of the company's equity, and also reflects whether the company is stable. This paper chooses the proportion of the first largest shareholder to represent the equity concentration.

2) Capital structure

Capital structure refers to the value structure of enterprise capital and its proportional relationship. To a certain extent, it reflects the financing situation of enterprises. If the way of finance is debt, the high debt ratio can result in the large financial leverage, and then affects the operational efficiency. This paper chooses asset-liability ratio to represent the capital structure.

3) Profitability

Profitability is the ability to make a profit. When a company is pursuing high profits, it can show that the operating efficiency of the enterprise is higher. In this paper, net interest rates are used to show the profitability of the enterprise.

4) Staff education

Employee education refers to higher level of education for every worker. Education has a certain role in promoting the development of productive forces. In this paper, the percentage of employees with higher education is selected to represent the degree of education.

\subsection{Research Hypothesis}

Based on the above-mentioned factors affecting the efficiency of enterprises, this 
paper makes the following assumptions:

1) Hypothesis 1: Other things equal, there is a negative correlation between equity concentration and technical efficiency. According to the principles of economy, it is possible for the majority shareholder to damage the efficiency of the whole company in order to maximize the personal interests.

2) Hypothesis 2: Other things equal, there is a negative correlation between asset-liability ratio and technical efficiency. In general, the more the companies loan, the larger they need to pay the interest.

3) Hypothesis 3: Other things equal, there is a positive correlation between net interest rates and technical efficiency. The higher net interest rates, the more flexible the company's ability to use assets.

4) Hypothesis 4: Other things equal, there is a positive correlation between staff education and technical efficiency. High quality labors will bring more inspiration to create greater value for the company.

According to the above research, this paper constructs the following test mod$\mathrm{el}$ and uses regression method to test the hypothesis.

\subsection{Empirical Results and Analysis}

In this part, we will take the panel data of 30 example companies collected during 2009-2015 as foundation, and make the overall efficiency values obtained from the previous DEA model as the explained variables, 4 influencing factors as the explaining variables. According to the DEA model, the range of overall efficiency is $[0,1]$, so the data are not continuous. Using least squares method to calculate is invalid because the parameter estimates are biased and inconsistent. To avoid this limitation, this paper uses Tobit regression model to analyze. The model is as follows:

$$
y=\beta+\alpha^{\mathrm{T}} x_{i}+u_{i}, i=1,2, \cdots, 33
$$

where dependent variable $y_{i}$ is overall efficiency, explaining variables $x_{i}$ is influencing factors, $\alpha$ is coefficient of explaining variable.

$X=\left[x_{1}, x_{2}, x_{3}, x_{4}\right], \mu \sim N\left(0, \delta^{2}\right) . X_{1}$ is the proportion of the first largest shareholder, $X_{2}$ is asset-liability ratio, $X_{3}$ is net interest rates, $X_{4}$ is the percentage of employees with higher education. By using Tobit model for regression analysis, we can determine the influencing factors and how they affect the efficiency of real estate enterprises.

This paper uses Stata 11 software to do the Tobit regression analysis of the panel data. The result is shown in Table 5.

We analyze and explain the results above:

1) The correlation coefficient of the largest shareholder is positive, but its concomitant probability is 0.514 , that means this index and efficiency of companies are not significantly related. This paper refers to the research of other scholars (Wang Jianqiang et al. 2010) in this area, and believes that when the equity is dispersed, the shareholders have the power to balance, and encourage the management to run the company transparently [22]; when the equity is concentrated, 
Table 5. Regression results of Tobit model.

\begin{tabular}{ccccc}
\hline Explaining variables & Coefficient & $\begin{array}{c}\text { Standard } \\
\text { deviation }\end{array}$ & T value & $\begin{array}{c}\text { Concomitant } \\
\text { probability }\end{array}$ \\
\hline $\begin{array}{c}\text { The proportion of the first largest } \\
\text { shareholder }\end{array}$ & 0.0059481 & 0.0023692 & 2.45 & 0.514 \\
$\begin{array}{c}\text { Asset-liability ratio } \\
\text { Net interest rates }\end{array}$ & -0.0027357 & 0.0035417 & -0.09 & 0.008 \\
$\begin{array}{c}\text { The percentage of employees with } \\
\text { higher education }\end{array}$ & 0.0424893 & 0.0035291 & 1.29 & 0.007 \\
$\quad$ Constant & 0.0421682 & 0.00167255 & 0.25 & 0.006 \\
\hline
\end{tabular}

Note: $95 \%$ confidence interval.

a few shareholders have a greater power to "dictate", and more easy to erode the interests of the company.

2) The correlation coefficient of the asset-liability ratio is negative, and the concomitant probability is low. It indicates that this index and the efficiency are negatively related. Asset-liability ratio is the ratio of total liabilities to total assets. For the operators, the higher the value, the more funds company loans, so the more interest payments are paid. Some enterprises' asset liability ratio reaches $90 \%$. The majority of enterprises maintains a high level of asset liability ratio, and show an upward trend.

3) The correlation coefficient of the net interest rate is positive, and the concomitant probability is low, that means this index and efficiency are positive related. The net interest rate measures the ability of the enterprise to use all the assets to gain the benefit. In the case of the total assets of enterprises remain unchanged, an increase in net interest rate, indicating that the better the level of input and output, the more improved the efficiency.

4) The correlation coefficient of percentage of employees with higher education is negative, and concomitant probability is low. It indicates that this index and the efficiency are positive related. Employees are an intangible asset. However, Zhao Qiong pointed when introducing some other explaining variables, statistical significance between education level and efficiency will drop [23]. It shows that education has an impact on the efficiency, but it's not the main factor.

\section{Conclusions}

DEA method has been the most popular method to explain the efficiency for decades. This method fits very well with empirical observations; therefore, it is popular with economists, although it has some shortcomings and limitations. In this paper, DEA method and Tobit model are used to analyze the operating efficiency and influencing factors of the listed real estate companies. The empirical results show that:

1) Although the real estate enterprises develop with a high speed, the quality of its development needs to be improved. In recent years, the efficiency of pure technology tends to decline, which reflects that the companies expand their scale, 
but at the same time, lead to production redundancy inevitably. Besides, the trend of scale efficiency is also declining, indicating that the resources of real estate companies have not allocated properly, and also the size of the configuration needs to be further optimized.

2) Technical efficiency can also be achieved through the improvement of scale efficiency. With respect to scale efficiency, the number of companies which are in a state of increasing return of scale becomes less. It sheds light on that listed real estate companies should focus on improving productivity and technological innovation.

Based on the above research results, the following suggestions are put forward:

First of all, a real estate company should consider an alternative way to finance themselves than making loan from banks but issuing bonds or establish financing sources in order to expand efficiency of financing the company.

Second, some real estate enterprises have the phenomenon of unreasonable asset size, low efficiency of funds usages. Real estate enterprises should establish a scientific financial and performance appraisal index system, so as to improve the use of funds.

What's more, in the changing market environment, real estate enterprises should take the market and customer's demands as the guidance, and make both the rationality and the strategic marketing strategy.

\section{References}

[1] Liu, Y.L., Hu, Y.J. and Zhang, F.J. (2005) Performance Analysis of Real Estate Listed Companies Based on DEA. Statistics and Decision, No. 14, 64-66.

[2] Zhang, B. (2006) Real Estate Listed Companies Operating Performance Evaluation. Statistics and Decision, No. 04, 55-57.

[3] Meng, C.J., Xing, F. and Chen, Y. (2008) Efficiency Evaluation of real Estate Enterprises Based on DEA. Management Review, No. 07, 57-62 + 64 .

[4] Yuan, F. and Gao, Y. (2009) Operation Efficiency Evaluation and optimization Analysis of China's Real Estate Industry by DEA-Based on the 20 Example Companies Collected during 2000-2007. Modern Business, No. 14, 60-62.

[5] Fu, C.X. and Hao, F.X. (2010) Analysis on the Operational Efficiency of China's Real Estate Industry. Economic Forum, No. 09, 20-23.

[6] He, Z.Y. (2015) Study on the Efficiency of China's Real Estate Industry under the Land Cost. East China Economic Management, No. 03, 79-84.

[7] Wang, T. and Wang, G. (2009) Empirical Analysis on Operational Efficiency of China's Real Estate Industry. Science and Technology and Industry, 10, 39-43 + 56.

[8] Ju, S. (2007) The Performance Evaluation of the Real Estate Company and the Analysis of Influencing Factors of the Performance. Master Thesis, Nanjing Agricultural University, Nanjing.

[9] Shen, C.J. (2013) Listed Real Estate Enterprise Performance Evaluation-Based on DEA and Malmquist Method. Master Thesis, Chongqing Jiaotong University, Chongqing.

[10] Zhou, Z.H., Li, X.S. and Zhang, Z.Y. (2007) Research on Listed Companies Reforming Real Estate Efficiency Based on DEA. Management Review, No. 06, 43-49 + 64 . 
[11] Lu, J. and Zuo, X. (2010) Analysis on Efficiency and Influencing Factors of Listed Real Estate Companies in China Based on Super Efficiency DEA-Tobit Model. Luojiashan Management Review, 2, 156-162.

[12] Zhang, H., Gao, S. and Zhang, Y. (2015) An Analysis of the Impact of Corporate Governance on Firm Performance from Multiple Perspectives: Evidence from China's Real Estate Listed Corporation. Journal of Nanjing Audit University, 2, 3-11.

[13] Charnes, A., Cooper, W.W. and Rhodes, E. (1978) Measuring the Efficiency of Decision Making Units. European Journal of Operational Research, 6, 429-444.

[14] Ramanathan, R. (2003) An Introduction to Data Envelopment Analysis: A Tool for Performance Measurement. Sage Publications, New Delhi.

[15] Silva, T.C., Tabak, B.M., Cajueiro, D.O. and Dias, M.V.B. (2017) A Comparison of DEA and SFA Using Micro- and Macro-Level Perspectives: Efficiency of Chinese Local Banks. Statistical Mechanics and Its Applications, 469, 216-223.

[16] Dong, P., Qiao, K. and Yang, M. (2015) Operational Efficiency across the Chinese Aerospace Industry: A DEA and Malmquist Analysis. Chinese Management Studies, 9, 553-570. https://doi.org/10.1108/CMS-07-2015-0142

[17] Xiong, C., Yi, Y.M., He, X. and Xiao, R. (2014) A Study on Operational Efficiency of Hi-Tech Startups in China Based on DEA Methods. Management Science, 2, 26-37.

[18] Banker, R., Charnes, A. and Cooper, W. (1984) Some Models for Estimating Technical Scale Inefficiencies in Data Envelopment Analysis. Management Science, 30, 1078-1092. https://doi.org/10.1287/mnsc.30.9.1078

[19] Liu, Y. and Sun, Z. (2006) Evaluation of the Operational Efficiency of Listed Real Estate Companies by DEA. Statistics and Information Forum, 1, 74-78.

[20] Ran, M. and Xu, B. (2013) Using a DEA-PNN Approach to Model the Efficiency of Real Estate Public Company. Journal of Chongqing University (Social Science Edition), 3, 59-64.

[21] Shi, J. and Yang, J. (2006) Evaluation of Real Estate Listed Company Performance by DEA. Journal of Shanghai University (Natural Science Edition), 3, 325-330.

[22] Wang, J. and Yang, J. (2010) Enterprise Investment Efficiency Evaluation Based on DEA Model. Science Research Management, 4, 73-80.

[23] Zhao, Q. and Jiang, H. (2014) Efficiency Evaluation and Influencing Factors of Cultural Industry Listed Companies-Based on the Framework of DEA Model. Economic Issues, 9, 52-58 + 71 .

\section{Submit or recommend next manuscript to SCIRP and we will provide best service for you:}

Accepting pre-submission inquiries through Email, Facebook, LinkedIn, Twitter, etc. A wide selection of journals (inclusive of 9 subjects, more than 200 journals)

Providing 24-hour high-quality service

User-friendly online submission system

Fair and swift peer-review system

Efficient typesetting and proofreading procedure

Display of the result of downloads and visits, as well as the number of cited articles

Maximum dissemination of your research work

Submit your manuscript at: http://papersubmission.scirp.org/

Or contact ib@scirp.org 